\title{
A review on green supply chain aspects and practices
}

\author{
Shamimul ISLAM \\ Universiti Sains Malaysia, Penang, Malaysia \\ shamimasaub@gmail.com \\ Noorliza KARIA \\ Universiti Sains Malaysia, Penang, Malaysia \\ Firdaus Bin Ahmad FAUZI \\ Universiti Sains Malaysia, Penang, Malaysia \\ Mohamed Soliman Mohamed SOLIMAN \\ Universiti Sains Malaysia, Penang, Malaysia
}

\begin{abstract}
The field of green supply chain is expanding rapidly, and new authors are venturing in this field to conduct further research. Although some literature reviews have beeen conducted over time, a complete list of green supply chain practices is not available. Hence, the objective of this study is to present an up-to-date list of green supply chain practices. To achieve this, the study employed structured review process, as well as critically examined the contents to ensure that the data are filtered from high-quality peer-reviewed journals and from influential authors in this field. 91 highquality papers were selected from top ten journals in GSCM area to produce the list. A total of 58 green supply chain practices comprising 15 aspects were featured, e.g. reverse logistics, industrial symbiosis, green information technology, green design, carbon management etc. This paper contributes to the existing literature by providing a comprehensive list of aspects and practices of the green supply chain. Finally, limitations and directions for future studies are provided in the conclusion section.
\end{abstract}

Keywords: green supply chain; green supply chain practice; GSCM; literature review; sustainable practice; green practice.

Please cite the article as follows: Islam, S., Karia, N., Fauzi, F.B.A and Soliman, M.S.M. (2017), "A review on green supply chain aspects and practices", Management and Marketing. Challenges for the Knowledge Society, Vol. 12, No. 1, pp. 12-36. DOI 10.1515/mmcks-2017-0002.

\section{Introduction}

Green supply chain (GSC) is an important issue for competition and for changing the competitive landscape in many industries. Current demand for value creation efforts, i.e. environmental and industrial sustainability, green and sustainable innovations have increased attention on the concept of GSC. Consequently, GSC has been integrated as a firm's innovative strategy which may lead a firm to achieve competitive advantage (Bititci et al., 2012). However, not many firms have integrated GSC practices. Although GSC has been acknowledged over a couple of decades, there are inconsistent arguments and 
inconclusive findings from the existing supply chain literature. Due to these shortcomings, the existing literature fails to understand what constitute the overall GSC practices.

The emergence of green supply chain management (GSCM) took place about a couple of decades ago, and now in its third decade for further discovery of knowledge in this field. When researchers started to integrate the environmental concerns into the supply chain, the concept of green supply chain emerged. The integration of economic, environmental and social facets has been at the forethought of sustainability in today's operations management due to the successful implementation of green supply chain which eventually has led to overall sustainability of firms. Therefore, the concept of green supply chain management received escalating attention in the last decade, and has uncovered ample opportunities for research in this area.

Researchers conducted a number of literature reviews on green supply chain management (Fahimnia et al., 2015; Govindan et al., 2015; Igarashi et al., 2013; Malviya and Kant, 2015; Min and Kim, 2012; Srivastava, 2007; Soda et al., 2016). Some of the authors tried to address the methodology part of the GSCM literature (Govindan et al., 2015; Soda et al., 2016) while others focused on the entire field of GSCM literature (Srivastava, 2007; Malviya and Kant, 2015). Additionally, few authors mixed the term green with sustainability in reviewing GSCM literature (Fahimnia et al., 2015). However, none of these reviews highlighted the comprehensive list of green supply chain practices. Though few authors attempted to address this issue in the past (Srivastava, 2007), those reviews were done many years back. By this time many green initiatives and developments have taken place in this field. Hence, the research work in GSCM is growing exponentially. Under this circumstance, researchers are finding difficulties to explicate what constitutes green supply chain practices. A comprehensive list of green practices is necessary in order to expedite future research in this filed. Ovearall, the objective of this paper is to present a comprehensive list of green supply chain practices (GSCP).

In order to develop a comprehensive list of GSCP, an extensive literature review has been conducted. The title containing the term "green supply chain" was targeted and the range of databases was 1998 to 2016. The screening process included a rigorous initial screening of limited number of papers to ensure that data are coming from high-quality peer-reviewed publications only. A total of 91 articles were selected for review for developing the list. This list was arranged according to different aspects or categories, and each aspect then has a list of practices. However, this study did not include the aspects and lists of sustainable supply chain management because green supply chain focuses only environmental and economic issue, while sustainable supply chain focuses on social, economic and environmental issues.

Finally, the theoretical and managerial contributions of this paper are twofold: first, this article contributes to the existing literature by providing a comprehensive list. Second, researchers, academicians, managers and policy makers can get the full lists of GSCP for further investigations and research. 
The rest of the paper begins with the definition of green supply chain management in Section 2; Section 3 outlines the structured methodology used in this study to identify the GSCM aspects and lists. An intensive literature review on green supply chain aspects and lists has been presented in section 4 along with the targeted list. Section 5 identifies some limitations and directions for future research.

\section{Literature review}

\section{Defining green supply chain management (GSCM)}

The practice of GSCM is getting popularity among operations managers especially with those who are pursuing the environmental performance of their opeartion. GSCM had a significant development and a geometric growth in academic publications over the last few decades, particularly during the late 1980s and early 1990s varying from primarily practical and conceptual advances in empirical and theoretical studies (Seuring and Müller, 2008; Srivastava, 2007). Previous studies indicated that the relative importance of these practices can be simply traced back to the beginning of environmental management movement during the late 1960s (Sarkis et al., 2011). According to Seuring and Müller (2008) the field of GSCM has commenced to be further formal and established particularly after the 1990s.

The Green Supply Chain Management (GSCM) concept is broad and there is no clear holistic definition available to describe it. Since the concept is defined differently by researchers, it is difficult to describe GSC by a single definition(Ahi and Searcy, 2013). The following table provides a list of GSC definitions in a chronological order. Based on table 1, researchers have used various keywords in defining GSC. Although defined differently, the meanings of GSC shown in the table involve the usage of several terms such as sustainable supply network management, supply and demand sustainability in corporate social responsibility networks, sustainable supply chains, green purchasing and procurement, supply chain environmental management, green logistics and environmental logistics, and environmental purchasing. Yet, based on the previous definitions, GSCM can be safely defined as integrating environmental concerns into the inter-organizational practices of supply chain management during a product's life cycle.

Table 1. Compilation of GSCM definitions

\begin{tabular}{|l|l|}
\hline \multicolumn{1}{|c|}{ Source } & \multicolumn{1}{c|}{ Definition } \\
\hline $\begin{array}{l}\text { (Handfield et al., } \\
\text { 1997) }\end{array}$ & $\begin{array}{l}\text { Application of environmental management principles to the entire set of activities } \\
\text { across the whole customer order cycle, including design, procurement, manufacturing } \\
\text { and assembly, packaging, logistics, and distribution. }\end{array}$ \\
\hline $\begin{array}{l}\text { (Zhu et al., } \\
\text { 2005) }\end{array}$ & $\begin{array}{l}\text { An important new archetype for enterprises to achieve profit and market share } \\
\text { objectives by lowering their environmental risks and impacts while raising their } \\
\text { ecological efficiency. }\end{array}$ \\
\hline (Hervani et al., & Green Purchasing + Green Manufacturing/Materials Management + Green \\
\hline
\end{tabular}

Vol. 12, No. 1, Spring, pp. 12-36, ISSN 1842-0206 | Management and Marketing. Challenges for the Knowledge Society 


\begin{tabular}{|c|c|}
\hline 2005) & Distribution/Marketing + Reverse Logistics \\
\hline $\begin{array}{l}\text { (Sheu et al., } \\
\text { 2005) }\end{array}$ & $\begin{array}{l}\text { Combination of both the product manufacturing supply chain and used-product reverse } \\
\text { logistics chain. }\end{array}$ \\
\hline $\begin{array}{l}\text { (Srivastava, } \\
\text { 2007) }\end{array}$ & $\begin{array}{l}\text { Integrating environmental thinking into supply-chain management, including product } \\
\text { design, material sourcing and selection, manufacturing processes, delivery of the final } \\
\text { product to the consumers as well as end-of-life management of the product after its } \\
\text { useful life. }\end{array}$ \\
\hline $\begin{array}{l}\text { (H'Mida and } \\
\text { Lakhal, 2007) }\end{array}$ & $\begin{array}{l}\text { The practice of monitoring and improving environmental performance in the supply } \\
\text { chain during a product's life cycle. }\end{array}$ \\
\hline $\begin{array}{l}\text { (Lakhal et al., } \\
\text { 2007) }\end{array}$ & $\begin{array}{l}\text { Olympic green supply chain characterized by five-circled flag of the Olympics as zero } \\
\text { emissions, zero waste in activities, zero waste of resources, zero use of toxic substances, } \\
\text { zero waste in product life-cycle, in addition to green inputs and green outputs. }\end{array}$ \\
\hline $\begin{array}{l}\text { (Srivastava, } \\
\text { 2008) }\end{array}$ & $\begin{array}{l}\text { Integration of sound environmental management choices with the decision-making } \\
\text { process for the conversion of resources into usable products. }\end{array}$ \\
\hline $\begin{array}{l}\text { (Lee and } \\
\text { Klassen, 2008) }\end{array}$ & $\begin{array}{l}\text { A buying organization's plans and activities that integrate environmental issues into } \\
\text { supply chain management in order to improve the environmental performance of } \\
\text { suppliers and customers. }\end{array}$ \\
\hline $\begin{array}{l}\text { (Albino et al., } \\
\text { 2009) }\end{array}$ & $\begin{array}{l}\text { A strategic approach addressed to extend environmental measures to the whole supply } \\
\text { chain. }\end{array}$ \\
\hline $\begin{array}{l}\text { (Wee et al., } \\
\text { 2011) }\end{array}$ & $\begin{array}{l}\text { Integration of environment considerations into supply chain management, including } \\
\text { product design, material sourcing and selection, manufacturing processes, delivery of } \\
\text { the final product to the consumers, and end-of-life management of the greening } \\
\text { products. }\end{array}$ \\
\hline $\begin{array}{l}\text { (Gavronski et } \\
\text { al., 2011) }\end{array}$ & $\begin{array}{l}\text { The complex of mechanisms implemented at the corporate and plant level to assess or } \\
\text { improve the environmental performance of a supplier base. }\end{array}$ \\
\hline $\begin{array}{l}\text { (Lorentz et al., } \\
\text { 2011) }\end{array}$ & Integrating environmental thinking into closed-loop supply chain management. \\
\hline $\begin{array}{l}\text { (Guiffrida et al., } \\
\text { 2011) }\end{array}$ & The environmental dimension of sustainability in a supply chain context. \\
\hline $\begin{array}{l}\text { (Wu and Pagell, } \\
\text { 2011) }\end{array}$ & $\begin{array}{l}\text { An approach that aims to integrate environmental issues into SC management } \\
\text { procedure starting from product design, and continuing through material sourcing and } \\
\text { selection, manufacturing processes, the final product delivery and end-of-life } \\
\text { management. }\end{array}$ \\
\hline $\begin{array}{l}\text { (Yeh and } \\
\text { Chuang, 2011) }\end{array}$ & $\begin{array}{l}\text { Management between suppliers, their products and environment, that is to say, the } \\
\text { environment protection principle is brought into suppliers' management system. Its } \\
\text { purpose is to add environment protection consciousness into original products and to } \\
\text { improve competitive capacity in markets. }\end{array}$ \\
\hline $\begin{array}{l}\text { (Sarkis et al., } \\
\text { 2011) }\end{array}$ & $\begin{array}{l}\text { Integrating environmental concerns into the inter-organizational practices of SCM } \\
\text { including reverse logistics. }\end{array}$ \\
\hline $\begin{array}{l}\text { (Kim et al., } \\
\text { 2011) }\end{array}$ & $\begin{array}{l}\text { A set of practices intended to effect, control and support environmental performance by } \\
\text { allocating possible human material resources and redefining organizational } \\
\text { responsibilities and procedures. }\end{array}$ \\
\hline $\begin{array}{l}\text { (Parmigiani et } \\
\text { al., 2011) }\end{array}$ & $\begin{array}{l}\text { A way for firms to achieve profit and market share objectives by lowering } \\
\text { environmental impacts and increasing ecological efficiency. }\end{array}$ \\
\hline $\begin{array}{l}\text { (Andiç et al., } \\
\text { 2012) }\end{array}$ & $\begin{array}{l}\text { Minimizing and preferably eliminating the negative effects of the supply chain on the } \\
\text { environment. }\end{array}$ \\
\hline
\end{tabular}

Source: Ahi and Searcy (2013).

Vol. 12, No. 1, Spring, pp. 12-36, ISSN 1842-0206 | Management and Marketing. Challenges for the Knowledge Society 


\section{Research methodology}

The well prepared literature reviews are usually developed through a reiterated process of defining proper keywords for search, searching the literature, and finalizing the analysis (Saunders, 2011). The purpose of literature reviews by illustrating and assessing the literature is to indicate latent research gaps along with highlighting the knowledge limitations (Tranfield et al., 2003). Furthermore, a structured methodology emphasizes on scanning the resources, planning the mind map to structure the literature review, writing the study and constructing the bibliography (Rowley and Slack, 2004). This study used a five-step methodology in a similar approach for collecting data and evaluating comprehensively. Based on this method, this study evaluated the field aiming to provide insights into current research interests and guidelines for future studies.

\section{Keywords used in search engine}

At the beginning the keywords used in the search engine included "green", "supply chain", "green practices", "environmental", "GSCM", and "GSCP". The combinations of search keywords used in google scholars were (1) green supply chain; (2) environmental and supply chain; and (3) GSCM. Operations and designs are the main two perspectives of the green supply chain. Therefore, it was ensured that the keywords completely cover both perspectives. This study did not consider sustainable supply chain and closed-loop supply chains as green supply chain.

\section{The result of the initial search}

Google Scholars provided ample range of related journals. Since USM's library already subscribed to all the major databases, integrated with Google Scholar, it was efficient to use this search engine for initial search. Our search keywords were restricted to the title of the paper. Initially the result of the search included conference papers, books, and books chapter but later we excluded them from our consideration. At first 31889 articles were derived using three combinations of keywords. Table 2 represents the result of initial search of Google Scholar.

Table 2. The initial results of search in Google Scholar

\begin{tabular}{|l|l|}
\hline Keywords & $\begin{array}{l}\text { Results (no. of } \\
\text { articles) }\end{array}$ \\
\hline Green Supply Chain & 2270 \\
\hline Environmental AND Supply Chain & 789 \\
\hline GSCM & 130 \\
\hline Total & 3189 \\
\hline
\end{tabular}

Source: Authors' own research.

\section{Refinement of the search results}

Referring to table 2, many papers appeared in more than one search category. 2380 papers remained after eliminating these duplications. Among the excluded papers were short non- 
refereed articles, while others were not regarded as scientific contributions. Further refinement has been performed to remove insignificant commercial magazine papers, nonrefereed articles, and those with unknown author names. In the end, 180 journal articles were critically selected from peer-reviewed and trusted publishers for our evaluation; these articles were published between 1998 and 2016.

\section{Data statistics}

In order to ensure the reliability of the data, this study collected its data from the top journals. Articles published between 1998 to 2016 by influential authors have been considered for evaluation. A total of 91 articles were selected from the top and most cited journals. The initial statistics showed that 59 journals have contributed to the publication of 180 papers. It was found that top 10 journals have published approximately $50 \%$ of all articles published, and they are the most cited journals in the field. For example, the Journal of Cleaner Production and International Journal of Production Economics are the top one and two journals respectively. Hence, the sources used for this study were proven to be reliable and top notch.

Table 3. The top 10 popular journals in GSCM area based on no of publications

\begin{tabular}{|l|c|}
\hline Name of the journals & No. of articles \\
\hline Journal of Cleaner Production & 18 \\
\hline International Journal of Production Economics & 14 \\
\hline International Journal of Production Research & 11 \\
\hline Business Strategy and the Environment & 8 \\
\hline Supply Chain Management: An International Journal & 7 \\
\hline Environmental Science and Technology & 6 \\
\hline Computer Aided Chemical Engineering & 6 \\
\hline Ecological Economics & 5 \\
\hline International Journal of Physical Distribution and Logistics Management & 5 \\
\hline International Journal of Life Cycle Assessment & 4 \\
\hline Journal of Industrial Ecology & 4 \\
\hline Sustainability & 3 \\
\hline Total & 91 \\
\hline
\end{tabular}

Source: Authors' own research.

\section{Green supply chain management (GSCM) practices}

Scholars discussed green supply chain practices from different aspects. Tseng et al. (2015) mentioned interrelationships among suppliers to reduce hazardous materials. Govindan et al. (2015), Rao and Holt (2005), Srivastava (2007), Walker et al. (2008) and Chen et al. (2011) identified GSCM practices that consist of reverse logistics, product recovery and reuse of used products, green design, green purchasing, and collaboration with suppliers and customers. Additionally some other scholars discussed internal management support 
(Zhu and Sarkis, 2004), customer environmental collaboration (Lawson et al., 2006), green manufacturing (De Giovanni, 2012), green packaging (González-Torre et al., 2004) and even green marketing (Van Hoek, 1999) while referring to GSCM practices of firms. Therefore, successful implementation of green supply chain can be done through various practices and initiatives (Rao and Holt, 2005) and (Srivastava, 2007). The practices and initiatives of green supply chain that have been discussed in the previous literature can be categorized into following aspects:

\section{Reverse logistics}

Reverse logistics is a significant practice of green supply chain. Logistics is forward activity, i.e. goods are delivered to customers from manufacturers or distributors. In contrast, in case of reverse logistics goods are moving back from customers to manufactures or distributors. As some parts of most of the products remain in the hand of customers after the end of its life, companies should have a system to recollect those items from the consumer to ensure an environment friendly world. This practice has been an important solution to operation management to recollect defective and unused items from the customers. In short, reverse logistics refers to collecting unused items, sorting and inspecting them, then recycling, reusing, remanufacturing, and disposal. The objectives of this practice are to protect environment from pollution by companies' unused items or end of life items, maximize the value of the unused items and minimize cost(Rao and Holt, 2005). GSCM not only focuses on environmental issues but also economic aspects too. An appropriate reverse logistic system should be designed to achieve efficiency and, thereby, achieve economic benefit for the company (Büyüközkan and Çifçi, 2012; Govindani et al., 2015; Srivastava, 2007).

\section{Industrial symbiosis}

The concept of industrial symbiosis refers to the association between two or more companies within industries in which the wastes of one partner become the raw materials for another. Firms can achieve competitive advantages in business management through eco-innovation, and industrial symbiosis makes a major contribution to achieving win-win status in supply-chain networks (Tseng and Bui, 2016). Industrial symbiosis is all about saving money and reducing consumption by working together to maximize the outputs that can be generated from resources. It is one approach to realizing a circular economy and achieving green growth (Berlina et al., 2016). The implementation of industrial symbiosis in the economy represents an innovative method to promote green economy and to create a new culture of economic growth (Albu, 2017).

\section{Green information technology and systems (GITS)}

Information Technology and Systems (ITS) are an important avenue to drive environmental footprints and sustainable practices (Bai and Sarkis, 2013; Koo and Chung, 2014; Molla et 
al., 2014; Sarkis et al., 2013). However, there has been a visible neglect of the IT function in environmental evaluation programs over the years (Savita, Dominic, and Ramayah, 2014). In the mining industry, equipment and employees use ITS. ITS use results in significant environmental footprints (Faucheux and Nicolaï, 2011; Uddin and Rahman, 2012). Green ITS can help mitigate these environmental footprints (Bhadauria et al., 2014) and optimize overall energy consumption of mines (Bilal et al., 2014). The use of eco-friendly hardware and data center, reducing waste of unused hardware, collaborative group software to minimize cost, and introducing telepresence to increase flexibility and buying eco-labeling of IT products are considered as green practices.

\section{Green design}

According to Fiksel and Fiksel (1996) and Tseng et al. (2013), green design reflects the design of products or services with certain environmental consciousness. It entails a systematic consideration of design issues, such as waste management, resource conservation and pollution prevention. Lin (2013) was in agreement by stating that green design is closely related to product safety, environmental risk management, resource conservation, waste management and pollution prevention. Along similar lines, Büyüközkan and Çifçi (2012) and Jabbour and Jabbour (2009) said that a well-designed product does not use hazardous or restricted materials during manufacturing and should minimize waste during production. In reference to today's green economy, Tseng et al. (2013) stated that the design of disassembly will be the strong base for the design of remanufacturing and recycling. This statement is supported by Tibben-Lembke (2002) stating that green design measurements include tracking all material and reverse flow of a product. In other words, green design should be able to trace and manage the retrieval of raw materials out of the environment, the disposal of the product back into the environment.

\section{Carbon management}

In 2009, the World Resource Institute announced a shocking truth. With increasing environmental and climate change worries in the green supply chain, $80 \%$ of carbon emissions were found to be produced through the supply chains (Hsu et al., 2013). Hence, carbon issues were quickly being recognized as an important element in GSCM; thus, many companies aimed to build a competency framework for carbon management (Lee, 2011). Lee (2011) further explained that companies began to monitor carbon footprints, and discover benefits such as decreased manufacturing costs, reduced total energy consumption, as well as impelling the consequences of carbon footprints externally. These were done especially to manage risks of climate change as well as increasing market share. Dwyer et al. (2009) emphasized 'carbon management' where suppliers engage to announce greenhouse gas emissions and set up reduction objects to manage their carbon emissions. To help with this, Sundarakani et al. (2010) forwarded a model for carbon emission 
computation and control across companies' supply chain to reduce the carbon footprint. In relation to that, Hsu et al. (2013) have summarized the main criteria for green supplier selection to facilitate carbon management program.

\section{Supplier environmental collaboration}

Vachon and Klassen (2006) identified that in effort to reduce environmental impact and seek for environmental solutions, organizations develop cooperative activities to handle environmental activities within the supply chain. Activities such as joint environmental planning, shared environmental knowledge, green product development and innovations which have a positive effect on delivery and supplier performance address the added value that can emerge from the direct collaborative interaction between organization and supply chain members (Bowen et al., 2001; Eltayeb et al., 2011; Govindan et al., 2015; Rao, 2002; Vachon and Klassen, 2007). These environmental collaboration helps companies manage suppliers' environmental performance, ensuring that the purchased materials are environment-friendly and produced using green processes (Lin, 2013; Rao and Holt, 2005; Zhu and Sarkis, 2007). Apart from that, this green practice intensifies the level of supply chain integration as other non-green supply chain practices involved with supplier collaboration do by enhancing the ability to organize operations in different supply chain tiers. Consequently, this practice could raise customer satisfaction, and reduce business waste and supply chain cost simultaneously (Azevedo et al., 2011; Gunasekaran et al., 2008).

\section{Customer environmental collaboration}

By managing collaborative interactions between organization and supply chain members, organizations build cooperative tasks to deal with environmental activities to decrease negative environmental effects within the supply chain (Lin, 2013). Customer environmental collaboration includes direct involvement of a firm to ensure better environmental performance for its customers. Eltayeb et al. (2011), Rao (2002) and Vachon and Klassen (2007) suggested activities like interchanging technical information between a company and its customers, customer education, customer support, and joint ventures which will eventually enhance environmental performance for customers in terms of green products and innovations development. An effective customer relationship, as explained by Azevedo et al. (2011), will allow environmental cost reduction, improve responsiveness to customers' environmental worries, increase customer satisfaction and reduce business waste.

\section{ISO 14001 certification}

In effort for enhancing their environmental performance, companies employ Environmental Management Systems (EMS) which include principles describing policies, procedures, and audit protocols to evaluate the environmental impact of an organization's operations. Among the most recognized EMS, as suggested by Nawrocka et al. (2009) and Robèrt (2000), is International Organization for Standardization (ISO) 14000 series. Driven by stakeholders, community and regulators under strict environmental regulations, ISO 14000 
standards were developed to prepare a direction towards developing a comprehensive method for environmental management and standardize the primary environmental tools (ISO, 2010; Prajogo et al., 2012). ISO 14001 can also act indirectly affecting all supply chain members to select more environmentally friendly practices. In addition, Azevedo et al. (2011) and Nawrocka et al. (2009) said it provides a basis for a systematic approach to reduce adverse environmental effects of organizations, decrease resource consumption and waste, and finally contribute to quality improvement.

\section{Internal management support}

Internal management support is crucial as it encompasses overall initiatives employed by an organization's top manager to implement green practices in the supply chain. As GSCM strategy is closely related to top management decisions, internal management support is vital (Olugu et al., 2011; Rao and Holt, 2005). The relationship between GSCM practices and internal management commitment has been emphasized by many researchers(Beamon, 1999; Hervani et al., 2005; Rao, 2002; Tsoulfas and Pappis, 2008). As an example, Carter et al. (1998) conducted an empirical study to consider GSCM practices, and it was found that management support and organization goals were essential to implementing GSCM practices successfully. Zhu and Sarkis (2004) and Lun (2011) identified factors affecting the internal environment namely 1) management liability from senior managers; 2) support from mid-level managers; and 3) cross-functional collaboration from environmental improvement. Olugu et al. (2011) added that the main measures of this practice comprise of: 1) accessibility of environmental evaluation systems; 2) availability of mission statements on sustainability; 3) the number of environmental management practices; 4) availability of environmental award systems; and 5) the management's attempt to motivate employees, customers and suppliers on sustainability.

\section{Green purchasing}

Green purchasing represents an ecologically conscious purchasing initiative that aims to ensure procured materials or components meet firms' eco-friendly goals. The purchasing process can manifest firms' environmental preferences if it includes green purchasing criteria (Carter and Ellram, 1998; Carter et al., 2000; Saghiri and Hill, 2014). Carter and Ellram (1998) argued that green purchasing also should reflect efforts to reduce, reuse, and recycle materials. For instance, to implement green principles into purchasing, companies can provide design instructions for suppliers. These designs could include the concept of environmental necessities like energy saving, cost reduction, using recyclable item, and such. Thus, purchasing decisions have significant influences on the sustainable supply chain (Yang et al., 2013) through the procurement of raw materials and components.

\section{Green manufacturing}

Research and development can design specifications for environmentally friendly products, and firms can re-engineer their manufacturing and production processes to rely on the 
addition of recyclable materials as part of the process. Green manufacturing considers environmental impacts throughout the product lifecycle including the sale of used, unsold, or returned products in secondary markets (Van Hoek, 1999). Green manufacturing entails the environmentally conscious production of a product with the goal of minimizing its negative environmental impacts throughout its entire life cycle as well as promoting positive ecological business operation practices such as recycling and reusing products (Walker et al., 2014). That is, green manufacturing considers environmental impacts in every stage of the product lifecycle (De Giovanni, 2012) to minimize the environmental impacts of manufacturing processes, generate minimum waste, and reduce environmental pollution. Pursuing green manufacturing also helps firms lower their raw material costs, gain production efficiency, reduce environmental and occupational safety expenses, and improve their corporate image (Zhu and Sarkis, 2007). Thus, green manufacturing helps firms achieve profit growth and increase their market share.

\section{Green packaging}

Examining current packaging can reveal possible changes and the potential of gathering leftover packaging or using less packaging (González-Torre, Adenso-Dí, and Artiba, 2004). Green packaging addresses all packaging issues including size, shape, and materials. Because reverse logistics entails a process of continuously taking back products or packaging materials to avoid environmental damages, it entails not just the use of recycled or recyclable materials but also the impacts of packaging on distribution arrangements such as loading and handling efficiency and space utilization. The packaging used must be less costly, easy to handle, and environmentally friendly (H.-J. Wu and Dunn, 1995). Finally, green packaging is the environmentally conscious packaging of a product to minimize the associated negative environmental impacts. Packaging contributes directly to product success in supply chains because it can enable the efficient distribution of products as well as lower environmental impacts due to spoilage or waste. Increased attention to global climate change has made green packaging a primary focus area to reduce waste and improve air quality because different packaging characteristics (e.g. size, shape, materials) have different impacts. (Hsu et al., 2016) indicated that green packaging includes considerations of cost (materials and shipping), performance (adequate protection of the product), convenience (easy to use), compliance (with legal requirements), and environmental impact (Lin et al., 2013; Liu et al., 2013).

\section{Green logistics}

González-Benito and González-Benito (2006) and Murphy and Poist (2000) stressed that among the green initiatives, green logistics received the least importance. While transportation systems actually have the most significant impacts on the environment, there are insufficient studies done on this from the standpoint of green logistics. The fatality and dangerousness of gas emissions resulting from transportation has never been a 
mystery for firms. Salimifard et al. (2012) confirmed that $15 \%$ of greenhouse gases and $23 \%$ of $\mathrm{CO}_{2}$ emissions are the direct results of the transportation sector alone. For 17 years since 1990, a recorded 45\% worldwide increase in CO2 emission was registered. It was then predicted that another 40\% increase will take place until 2030 endangering the health of all life forms on earth. Therefore, companies can achieve various economic benefits, e.g. through fuel efficiency, route and warehouse optimization and some value of environment/society by avoiding any activities that cause unnecessary carbon emissions (Karia and Asaari, 2016).

\section{Green outsourcing}

Tseng et al. (2011) said that for original equipment manufacturing (OEM) firms, green outsourcing performance (GOP) will be used as fundamental enablers and criteria for competitiveness. However, for practical adoption of GOP, there are not many studies which could provide integrated competitive advantages, enablers and criteria (called measures). In an intensive market, the firms should implement measures starting from competitive advantages to internal processes. Since green issues related to carbon mapping and greenhouse gases are important for all firms, responsible energy management is a crucial business capability as discussed by Babin and Nicholson (2011). For all outsourcing agents, environmental issues and the ability to demonstrate the environmentfriendly practices are becoming vital. Brown (2008) added to the discussion by stating that the influence of consumer and investor opinions for green corporate accountability as well as the creation of new government regulations for protecting the environment have pushed green issues onto the boardroom agenda and outsourcing vendors' growing plate of priorities.

\section{Green warehousing}

In an attempt to save cost and energy more firms have slowly understood the criticality of green warehousing. Many warehousing and fulfillment companies are looking to implement environmentally friendly practices that minimize their carbon footprint and reduce environmental pollution, and at the same time minimize their costs and increase social responsibility (Rostamzadeh et al., 2015). Although the number of green warehouses is increasing, the initial cost and time investment to convert to this kind of warehousing were considered huge by many firms.

\section{Summary of GSCM aspects and practices}

From the above discussion, the aspects and practices can be summarized. Table 4 presents the comprehensive lists of GSCM aspects and green practices.

Table 4. Summary table for aspects and practices

\begin{tabular}{|l|l|l|}
\hline GSCM aspects & Practices & Sources \\
\hline Reverse logistics & $1 . \quad$ Recovery of the company's end-of-life & Büyüközkan and Çifçi (2012); \\
\hline
\end{tabular}




\begin{tabular}{|c|c|c|}
\hline & $\begin{array}{ll}\text { items } \\
\text { 2. } \\
\text { compale or reuse of used parts or } \\
\text { 3. Old/obsolete items being used or replaced } \\
\text { 4. Recondition and refurbishing of used parts } \\
\text { or components }\end{array}$ & $\begin{array}{l}\text { Govindan et al. (2015); Srivastava, } \\
\text { (2007); Tseng and Chiu (2013, } \\
\text { 2012) }\end{array}$ \\
\hline $\begin{array}{l}\text { Industrial } \\
\text { symbiosis }\end{array}$ & $\begin{array}{l}\text { 5. Sharing waste treatment plants } \\
\text { 6. Helping suppliers to establish their own } \\
\text { environmental management system(EMS) } \\
\text { 7. Use of waste of other companies }\end{array}$ & $\begin{array}{l}\text { Berlina et al. (2016); Tseng and Bui } \\
\text { (2016); Albu (2017). Puente et al. } \\
\text { (2015); Mahmood et al. (2013); } \\
\text { Tseng and Chiu (2012) }\end{array}$ \\
\hline $\begin{array}{l}\text { Eco-Innovation } \\
\text { practices }\end{array}$ & $\begin{array}{l}\text { 8. Substituting toxic inputs with } \\
\text { environmentally friendly ones } \\
\text { 9. Switching from "dirty" to cleaner } \\
\text { technologies } \\
\text { 10. Internal recycling of wastes }\end{array}$ & $\begin{array}{l}\text { Crum et al. (2011);Rao and Holt } \\
\text { (2005) }\end{array}$ \\
\hline $\begin{array}{l}\text { Green } \\
\text { Information } \\
\text { Technology and } \\
\text { Systems }\end{array}$ & $\begin{array}{l}\text { 11. Use of energy efficient hardware and data } \\
\text { centers } \\
\text { 12. Consolidating servers using virtualization } \\
\text { software } \\
\text { 13. Reducing waste associated with obsolete } \\
\text { equipment } \\
\text { 14. telepresence systems } \\
\text { 15. Collaborative group software } \\
\text { 16. Eco-labeling of IT products }\end{array}$ & $\begin{array}{l}\text { Boudreau et al. (2008); Jenkin et al. } \\
\text { (2011); Chou and Chou (2012); } \\
\text { Setterstrom (2008); Standing et al. } \\
\text { (2008); Uddin and Rahman (2012) }\end{array}$ \\
\hline Green design & $\begin{array}{l}\text { 17. Design of products for reduced } \\
\text { consumption of materials/energy } \\
\text { 18. Intend to reduce products' negative effects } \\
\text { on the environment during its entire life } \\
\text { cycle } \\
\text { 19. Design of products for reuse, recycle, } \\
\text { recovery of materials, component parts } \\
\text { 20. Design the products to be easily set up for } \\
\text { the users in the most energy saving ways } \\
\text { 21. Design for reduction of environmentally } \\
\text { hazardous substances, design for recycling } \\
\text { waste and design for remanufacturing } \\
\text { aimed at returning it to a better condition }\end{array}$ & $\begin{array}{l}\text { Fiksel and Fiksel (1996); Gungor and } \\
\text { Gupta (1999);Arena et al. (2003); } \\
\text { Beamon (1999) ; Zhu et al. (2007); } \\
\text { Eltayeb et al. (2011); Lin (2013); } \\
\text { Tseng and Chiu (2012); Sarkis } \\
\text { (1998) }\end{array}$ \\
\hline $\begin{array}{l}\text { Carbon } \\
\text { management }\end{array}$ & $\begin{array}{l}\text { 22. Carbon reduction targets } \\
\text { 23. Training related to carbon management } \\
\text { 24. Emphasized supplier engagement to } \\
\text { announce greenhouse gas emissions and } \\
\text { set up reduction objects to manage their } \\
\text { carbon emissions. }\end{array}$ & $\begin{array}{l}\text { Govindan et al. (2015); Hsu et al. } \\
\text { (2013); Lee (2011) }\end{array}$ \\
\hline $\begin{array}{l}\text { Supplier } \\
\text { environmental } \\
\text { collaboration }\end{array}$ & $\begin{array}{l}\text { 25. Collaborate with suppliers to build } \\
\text { programs to reduce or eliminate waste } \\
\text { 26. Share environmental management } \\
\text { techniques and knowledge } \\
\text { 27. Monitor environmental compliance status } \\
\text { and practices of supplier's operations }\end{array}$ & $\begin{array}{l}\text { Lawson et al. (2006); Vachon and } \\
\text { Klassen (2006); Vachon and Klassen } \\
\text { (2008); Gunasekaran et al. (2008) }\end{array}$ \\
\hline
\end{tabular}

Vol. 12, No. 1, Spring, pp. 12-36, ISSN 1842-0206 | Management and Marketing. Challenges for the Knowledge Society 


\begin{tabular}{|c|c|c|}
\hline & $\begin{array}{l}\text { 28. Collaborate with suppliers to manage } \\
\text { reverse flows of materials and packaging } \\
\text { 29. Communicate goals of sustainability to } \\
\text { suppliers }\end{array}$ & \\
\hline $\begin{array}{l}\text { Customer } \\
\text { environmental } \\
\text { collaboration }\end{array}$ & $\begin{array}{l}\text { 30. Collaborate with customer to develop } \\
\text { environmental management solutions } \\
\text { 31. Collaborate with customer to manage } \\
\text { reverse flows of materials and packaging }\end{array}$ & $\begin{array}{l}\text { Lawson et al. (2006); Lin (2013); } \\
\text { Azevedo et al. (2011) }\end{array}$ \\
\hline $\begin{array}{l}\text { ISO } 14001 \\
\text { certification }\end{array}$ & $\begin{array}{l}\text { 32. Participating in environmental } \\
\text { certification such as ISO } 14001 \text { certificate. }\end{array}$ & $\begin{array}{l}\text { Nawrocka et al. (2009); Robèrt } \\
\text { (2000); ISO (2010); Prajogo et al. } \\
\text { (2012) }\end{array}$ \\
\hline $\begin{array}{l}\text { Internal } \\
\text { management }\end{array}$ & $\begin{array}{l}\text { 33. Environmental compliance monitoring } \\
\text { and auditing } \\
\text { 34. Total quality environment management } \\
\text { 35. Pollution prevention plans } \\
\text { 36. Environmental manager and training for } \\
\text { employees } \\
\text { 37. Employee incentive programs for } \\
\text { environmental suggestions }\end{array}$ & $\begin{array}{l}\text { Olugu et al. (2011); Rao and Holt } \\
\text { (2005); Tsoulfas and Pappis (2008); } \\
\text { Zhu and Sarkis (2004); Lawson et al. } \\
(2006)\end{array}$ \\
\hline Green purchasing & $\begin{array}{l}\text { 38. Choice of suppliers by considering the } \\
\text { environmental criteria } \\
\text { 39. Buying environment-friendly raw } \\
\text { materials } \\
\text { 40. Pressuring supplier(s) to take } \\
\text { environmental actions }\end{array}$ & $\begin{array}{l}\text { Carter and Ellram (1998); Carter et } \\
\text { al. (2000); Saghiri and Hill (2014); } \\
\text { Yang et al. (2013); Kannan et al. } \\
(2014)\end{array}$ \\
\hline $\begin{array}{l}\text { Green } \\
\text { manufacturing }\end{array}$ & $\begin{array}{l}\text { 41. Generate minimum waste, and reduce } \\
\text { environmental pollution. } \\
\text { 42. Re-manufacturing and lean production } \\
\text { 43. Cleaner production } \\
\text { 44. Improved capacity utilization } \\
\text { 45. Lower raw material costs, gain production } \\
\text { efficiency, and improve their corporate } \\
\text { image } \\
\text { 46. Increase amount of goods delivered on } \\
\text { time } \\
\text { 47. Does not use hazardous or restricted } \\
\text { materials during manufacturing and } \\
\text { minimize waste during production }\end{array}$ & $\begin{array}{l}\text { Walker et al. (2014); Tseng et al. } \\
\text { (2009); De Giovanni (2012); Zhu and } \\
\text { Sarkis (2007); Van Hoek (1999); } \\
\text { Tseng and Chiu }(2012,2013)\end{array}$ \\
\hline Green packaging & $\begin{array}{l}\text { 48. Environmentally friendly packaging (Eco- } \\
\text { packaging) } \\
\text { 49. Returnable packaging, reused packaging, } \\
\text { recyclable packaging. }\end{array}$ & $\begin{array}{l}\text { González-Torre et al. (2004); Wu } \\
\text { and Dunn (1995); Hsu et al. (2016); } \\
\text { Lin et al. (2013); Liu et al. (2013) }\end{array}$ \\
\hline Green Logistics & $\begin{array}{l}\text { 50. Environmentally friendly transportation } \\
\text { 51. Environment-friendly distribution } \\
\text { 52. Using green fuels such as low sulfur } \\
\text { content and alternative fuels such as liquid } \\
\text { natural gas. } \\
\text { 53. Community/environmental, employee } \\
\text { health and safety concerns while } \\
\text { transportation. }\end{array}$ & $\begin{array}{l}\text { González-Benito and González- } \\
\text { Benito (2006); Murphy and Poist } \\
\text { (2000); Enarsson (1998); Salimifard } \\
\text { et al. (2012) }\end{array}$ \\
\hline Green & 54. Care environmental responsibility in & Tseng et al. (2011); Babin and \\
\hline
\end{tabular}

Vol. 12, No. 1, Spring, pp. 12-36, ISSN 1842-0206 | Management and Marketing. Challenges for the Knowledge Society 


\begin{tabular}{|l|l|l|}
\hline outsourcing & \multicolumn{1}{|c|}{$\begin{array}{l}\text { global outsourcing. } \\
\text { 55. Display environmental-friendly culture to } \\
\text { all outsourcing stakeholders }\end{array}$} & Nicholson (2011); Brown (2008) \\
\hline $\begin{array}{l}\text { Green } \\
\text { warehousing }\end{array}$ & $\begin{array}{l}\text { 56. Decrease inventory levels } \\
\text { 57. Investment recovery (IR) (sale) of excess } \\
\text { inventories/materials } \\
\text { 58. Sale of excess capital equipment }\end{array}$ & Zhu et al. (2008) \\
\hline
\end{tabular}

Note: Few scholars highlighted recycle and reuse as another aspect, but it has correlation with green production and reverse logistics. Therefore, the two aspects were rather included in green practices. Additionally, "green transportation" was merged with "green logistics", and "end of life practices" merged with "reverse logistics" for the same reason.

Source: Authors' own research.

\section{Conclusions, limitations and suggestions for future research}

This study presented a comprehensive list of aspects and practices by reviewing literature from green supply chain management area. Articles published between 1998 and 2016 in top journals were reviewed. Although there are few literature reviews on green supply chain area but a comprehensive list of green practices has not been compiled in the past. A thorough and rigorous review of the influential articles has been done, and hopefully contributes to this field by documenting different aspects and practices of green supply chain.

It is found that there are fifteen aspects by which previous GSCM scholars categorized all green supply chain practices. Initially, only a few aspects such as green purchasing, green packaging, and green manufacturing were found in the literature. As the GSCM discipline is gradually growing, more and more young researchers are coming into this filed for further expanding the work in different fashions and in different sub disciplines. Conclusively, it can be said that these fifteen aspects and fifty-eight practices are the results of two decades' sincere efforts by GSCM scholars. For those who are seeking to do further research in GSCM area, this paper will definitely help them to narrow down their research focus conveniently. Moreover, the data have been collected from the most popular journals and from the most influential authors as well. These ground work will definitely be beneficial and informative for young researchers who have interest in GSCM.

More specifically, researchers who want to do research in evaluating the green supply chain practices (GSCP) in any industry they can use these fifteen aspects and practices. Previous studies did not use all aspects and practices while evaluating GSCP at firms' level. For example, Kusi-Sarpong et al. (2016) and Rostamzadeh et al. (2015) evaluated GSCP in mining and laptop manufacturing industries respectively using only six aspects. The inclusion of other aspects might have been produced more comprehensive insights. Thus, there is scarcity of literature that used all these fifteen aspects in evaluating 
GSCP. Therefore, this study directs researchers to use these aspects in evaluating GSCP to provide a rigorous result in their studies.

This paper has some limitations and, therefore, it suggests for future research. First, this compilation of aspects and practices is the outcome of different industries, and thus may not be applicable for researches focusing on specific industry. Resource based view theory suggests that each firm is different from others. Each industry is different from others in terms of its product, services and operations. Consequently, there are lots of room in this area for future research and exploration. Second, the list provided in this study is not necessarily final. It is a part of ongoing development and filing of researches in GSCM. It is hoped that the compilation keeps proceeding and continues to be a reliable source of information for future researchers. Third, the scope of the list was narrowed down to the top ten journals only. Hence, future study may encompass all the papers and journals in other ranks and fields as well. Fourth, many of the compilation works were made difficult by the definition where green practices were deemed to have similar meaning with sustainability practices. It is strongly suggested that any future research involving these two areas must clearly define their scope of research to ease the categorization. However, careful examination and focused review has been performed to eliminate the redundancy.

There are some limitations in how we gathered and presented the outcomes of the study. As a result, it is recommended that future work is better to enlarge the keywords to embrace sustainable supply chain, transportation, reverse logistics, logistics, shipping, inter-organizational efforts, alliances, partnering; indicating an extensive assortment of keywords could lead to a broader list of aspects and practices. To sum up, the GSCM discipline is growing along with opportunities for improvement on the ground that there exists a small number of dominant literature.

\section{References}

Ahi, P. and Searcy, C. (2013). "A comparative literature analysis of definitions for green and sustainable supply chain management", Journal of Cleaner Production, Vol. 52, pp. 329-341.

Albino, V., Balice, A. and Dangelico, R. M. (2009), "Environmental strategies and green product development: an overview on sustainability-driven companies", Business Strategy and the Environment, Vol. 18, No. 2, pp. 83-96.

Albu, A. (2017), "Industrial symbiosis: An innovative tool for promoting green growth", in Leal Filho, W., Pociovalisteanu, D.M. and Al-Amin, A.Q. (Eds.), Sustainable Economic Development, pp. 1-29, Springer, Berlin.

Andiç, E., Yurt, Ö. and Baltacıoğlu, T. (2012), "Green supply chains: Efforts and potential applications for the Turkish market", Resources, Conservation and Recycling, Vol. 58, pp. $50-68$. 
Arena, U., Mastellone, M. L. and Perugini, F. (2003), "The environmental performance of alternative solid waste management options: a life cycle assessment study", Chemical Engineering Journal, Vol. 96, No. 1, pp. 207-222.

Azevedo, S.G., Carvalho, H. and Machado, V.C. (2011), "The influence of green practices on supply chain performance: a case study approach", Transportation Research Part E: Logistics and Transportation Review, Vol. 47, No. 6, pp. 850-871.

Babin, R. and Nicholson, B. (2011), "How green is my outsourcer? Measuring sustainability in global IT outsourcing", Strategic Outsourcing: An International Journal, Vol. 4, No. 1, pp. 47-66.

Bai, C., and Sarkis, J. (2013), "Green information technology strategic justification and evaluation", Information Systems Frontiers, Vol. 15, No. 5, pp. 831-847.

Beamon, B.M. (1999), "Designing the green supply chain", Logistics Information Management, Vol. 12, No. 4, pp. 332-342.

Berlina, A., Mikkola, N. and Teräs, J. (2016), "Industrial symbiosis - A key driver of green growth in Nordic regions?", Retrieved from www.nordregio.se/en/Publications /Publications-2016/Industrial-Symbiosis---A-key-driver-of-Green-Growth-inNordic-Regions.

Bhadauria, V.S., Toms, L., Green Jr, K.W. and Meacham, J. (2014), "Do green information systems impact performance?", International Journal of Productivity and Quality Management, Vol. 13, No. 4, pp. 377-394.

Bilal, K., Malik, S.U.R., Khalid, O., Hameed, A., Alvarez, E., Wijaysekara, V. and Ali, M. (2014), "A taxonomy and survey on green data center networks", Future Generation Computer Systems, Vol. 36, pp. 189-208.

Bititci, U., Garengo, P., Dörfler, V. and Nudurupati, S. (2012), "Performance measurement: challenges for tomorrow", International Journal of Management Reviews, Vol. 14, No. 3, pp. 305-327.

Boudreau, M.-C., Chen, A. and Huber, M. (2008), "Green IS: Building sustainable business practices", Information Systems: A Global Text, pp. 1-17.

Bowen, F.E., Cousins, P.D., Lamming, R.C. and Farukt, A.C. (2001), "The role of supply management capabilities in green supply", Production and Operations Management, Vol. 10, No. 2, pp. 174-189.

Brown, D. (2008), "It is good to be green: environmentally friendly credentials are influencing business outsourcing decisions", Strategic Outsourcing: An International Journal, Vol. 1, No. 1, pp. 87-95.

Büyüközkan, G. and Çifçi, G. (2012), "A novel hybrid MCDM approach based on fuzzy DEMATEL, fuzzy ANP and fuzzy TOPSIS to evaluate green suppliers", Expert Systems with Applications, Vol. 39, No. 3, pp. 3000-3011. 
Carter, C.R. and Ellram, L.M. (1998), "Reverse logistics: a review of the literature and framework for future investigation", Journal of Business Logistics, Vol. 19, No. 1, pp. 85-97.

Carter, C.R., Ellram, L.M. and Ready, K.J. (1998), "Environmental purchasing: benchmarking our German counterparts", International Journal of Purchasing and Materials Management, Vol. 34, No. 3, pp. 28-38.

Carter, C.R., Kale, R. and Grimm, C.M. (2000), "Environmental purchasing and firm performance: an empirical investigation", Transportation Research Part E: Logistics and Transportation Review, Vol. 36, No. 3, pp. 219-228.

Chen, Y.-H., Tseng, M.-L. and Lin, R.-J. (2011), "Evaluating the customer perceptions on inflight service quality", African Journal of Business Management, Vol. 5, No. 7, pp. 2854-2867.

Chou, D.C. and Chou, A.Y. (2012), "Awareness of Green IT and its value model", Computer Standards and Interfaces, Vol. 34, No. 5, pp. 447-451.

Crum, M., Poist, R., Carter, C.R. and Easton, P.L. (2011), "Sustainable supply chain management: evolution and future directions", International Journal of Physical Distribution and Logistics Management, Vol. 41, No. 1, pp. 46-62.

De Giovanni, P. (2012), "Do internal and external environmental management contribute to the triple bottom line?", International Journal of Operations and Production Management, Vol. 32, No. 3, pp. 265-290.

Dwyer, R., Lamond, D., Wittneben, B.B. and Kiyar, D. (2009), "Climate change basics for managers. Management Decision", Vol. 47, No. 7, pp. 1122-1132.

Eltayeb, T.K., Zailani, S. and Ramayah, T. (2011), "Green supply chain initiatives among certified companies in Malaysia and environmental sustainability: Investigating the outcomes", Resources, Conservation and Recycling, Vol. 55, No. 5, pp. 495-506.

Enarsson, L. (1998), "Evaluation of suppliers: how to consider the environment", International Journal of Physical Distribution and Logistics Management, Vol. 28, No. 1, pp. 5-17.

Fahimnia, B., Sarkis, J. and Davarzani, H. (2015), "Green supply chain management: A review and bibliometric analysis", International Journal of Production Economics, Vol. 162, pp. 101-114.

Faucheux, S. and Nicolaï, I. (2011), "IT for green and green IT: A proposed typology of ecoinnovation", Ecological economics, Vol. 70, No. 11, pp. 2020-2027.

Fiksel, J. and Fiksel, J.R. (1996), Design for environment: creating eco-efficient products and processes, McGraw-Hill Professional Publishing.

Gavronski, I., Klassen, R.D., Vachon, S. and do Nascimento, L.F.M. (2011), "A resource-based view of green supply management", Transportation Research Part E: Logistics and Transportation Review, Vol. 47, No. 6, pp. 872-885. 
González-Benito, J. and González-Benito, Ó. (2006), "The role of stakeholder pressure and managerial values in the implementation of environmental logistics practices", International Journal of Production Research, Vol. 44, No. 7, pp. 1353-1373.

González-Torre, P.L., Adenso-Dí, B. and Artiba, H. (2004), "Environmental and reverse logistics policies in European bottling and packaging firms", International Journal of Production Economics, Vol. 88, No. 1, pp. 95-104.

Govindan, K., Khodaverdi, R. and Vafadarnikjoo, A. (2015), "Intuitionistic fuzzy based DEMATEL method for developing green practices and performances in a green supply chain", Expert Systems with Applications, Vol. 42, No. 20, pp. 7207-7220.

Govindan, K., Rajendran, S., Sarkis, J. and Murugesan, P. (2015), "Multi criteria decision making approaches for green supplier evaluation and selection: a literature review", Journal of Cleaner Production, Vol. 98, pp. 66-83.

Govindan, K., Soleimani, H. and Kannan, D. (2015), "Reverse logistics and closed-loop supply chain: A comprehensive review to explore the future", European Journal of Operational Research, Vol. 240, No. 3, pp. 603-626.

Guiffrida, A.L., Datta, P., El Saadany, A., Jaber, M. and Bonney, M. (2011), "Environmental performance measures for supply chains", Management Research Review, Vol. 34, No. 11 , pp. 1202-1221.

Gunasekaran, A., Lai, K.-H. and Cheng, T. E. (2008), "Responsive supply chain: a competitive strategy in a networked economy", Omega, Vol. 36, No. 4, pp. 549-564.

Gungor, A. and Gupta, S.M. (1999), "Issues in environmentally conscious manufacturing and product recovery: A survey", Computers and Industrial Engineering, Vol. 36, No. 4, pp. 811-853.

H'Mida, S. and Lakhal, S.Y. (2007), "A model for assessing the greenness effort in a product supply chain", International Journal of Global Environmental Issues, Vol. 7, No. 1, pp. 4-24.

Handfield, R.B., Walton, S.V., Seegers, L.K. and Melnyk, S.A. (1997), "'Green'value chain practices in the furniture industry", Journal of Operations Management, Vol. 15, No. 4, pp. 293-315.

Walker, H., Sarkis, J., Klassen, R., Dam, L. and Petkova, B. (2014), "The impact of environmental supply chain sustainability programs on shareholder wealth", International Journal of Operations and Production Management, Vol. 34, No. 5, pp. 586-609.

Hervani, A.A., Helms, M.M. and Sarkis, J. (2005), "Performance measurement for green supply chain management", Benchmarking: An International Journal, Vol. 12, No. 4, pp. 330-353.

Hsu, C.-C., Tan, K.-C. and Mohamad Zailani, S.H. (2016), "Strategic orientations, sustainable supply chain initiatives, and reverse logistics: Empirical evidence from an emerging 
market", International Journal of Operations and Production Management, Vol. 36, No. 1, pp. 86-110.

Hsu, C.-W., Kuo, T.-C., Chen, S.-H. and Hu, A.H. (2013), "Using DEMATEL to develop a carbon management model of supplier selection in green supply chain management", Journal of Cleaner Production, Vol. 56, pp. 164-172.

Igarashi, M., de Boer, L. and Fet, A.M. (2013), "What is required for greener supplier selection? A literature review and conceptual model development", Journal of Purchasing and Supply Management, Vol. 19, No. 4, pp. 247-263.

ISO (2010), The ISO Survey of Certifications 2009, International Organization for Standardization, Geneva.

Jabbour, A.B.L. and Jabbour, C.J. (2009), "Are supplier selection criteria going green? Case studies of companies in Brazil", Industrial Management and Data Systems, Vol. 109, No. 4, pp. 477-495.

Jenkin, T.A., Webster, J. and McShane, L. (2011), "An agenda for 'Green' information technology and systems research", Information and Organization, Vol. 21, No. 1, pp. 17-40.

Kannan, D., de Sousa Jabbour, A.B.L. and Jabbour, C.J.C. (2014), "Selecting green suppliers based on GSCM practices: Using fuzzy TOPSIS applied to a Brazilian electronics company", European Journal of Operational Research, Vol. 233, No. 2, pp. 432-447.

Karia, N. and Asaari, M.H.A.H. (2016), Transforming green logistics practice into benefits: a case of third-party logistics (3PLs), Paper presented at the International Conference on Industrial Engineering and Operations Management, Kuala Lumpur, Malaysia.

Kim, J.H., Youn, S. and Roh, J.J. (2011), "Green supply chain management orientation and firm performance: evidence from South Korea", International Journal of Services and Operations Management, Vol. 8, No. 3, pp. 283-304.

Koo, C. and Chung, N. (2014), "Examining the eco-technological knowledge of Smart Green IT adoption behavior: A self-determination perspective", Technological Forecasting and Social Change, Vol. 88, pp. 140-155.

Kusi-Sarpong, S., Sarkis, J. and Wang, X. (2016), "Assessing green supply chain practices in the Ghanaian mining industry: A framework and evaluation", International Journal of Production Economics, Vol. 181, No. B, pp. 325-341.

Lakhal, S., H'Mida, S. and Islam, M.R. (2007), "Green supply chain parameters for a Canadian petroleum refinery company", International Journal of Environmental Technology and Management, Vol. 7, No. 1-2, pp. 56-67.

Lawson, B., Squire, P.D.C., Vachon, B. and Klassen, R.D. (2006), "Extending green practices across the supply chain: the impact of upstream and downstream integration", International Journal of Operations and Production Management, Vol. 26, No. 7, pp. 795-821. 
Lee, K.-H. (2011), "Integrating carbon footprint into supply chain management: the case of Hyundai Motor Company (HMC) in the automobile industry", Journal of Cleaner Production, Vol. 19, No. 11, pp. 1216-1223.

Lee, S.Y. and Klassen, R.D. (2008), "Drivers and enablers that foster environmental management capabilities in small-and medium-sized suppliers in supply chains", Production and operations management, Vol. 17, No. 6, pp. 573-586.

Lin, C., Kuei, C.-H. and Chai, K.-W. (2013), "Identifying critical enablers and pathways to high performance supply chain quality management", International Journal of Operations and Production Management, Vol. 33, No. 3, pp. 347-370.

Lin, R.-J. (2013), "Using fuzzy DEMATEL to evaluate the green supply chain management practices", Journal of Cleaner Production, Vol. 40, pp. 32-39.

Liu, H., Ke, W., Kee Wei, K. and Hua, Z. (2013), "Effects of supply chain integration and market orientation on firm performance: Evidence from China", International Journal of Operations and Production Management, Vol. 33, No. 3, pp. 322-346.

Lorentz, H., Shi, Y., Hilmola, O.-P., Srai, J. and Hung Lau, K. (2011), "Benchmarking green logistics performance with a composite index", Benchmarking: An international Journal, Vol. 18, No. 6, pp. 873-896.

Lun, Y.V. (2011), "Green management practices and firm performance: A case of container terminal operations", Resources, Conservation and Recycling, Vol. 55, No. 6, pp. 559566.

Mahmood, W., Hasrulnizzam, W., Ab Rahman, M.N., Deros, B., Jusoff, K., Saptari, A., Bakar, A. (2013), "Manufacturing performance in green supply chain management", World Applied Sciences Journal, Vol. 21, pp. 76-84.

Malviya, R.K. and Kant, R. (2015), "Green supply chain management (GSCM): A structured literature review and research implications", Benchmarking: An International Journal, Vol. 22, No. 7, pp. 1360-1394.

Min, H. and Kim, I. (2012), "Green supply chain research: past, present, and future", Logistics Research, Vol. 4, No. 1-2, pp. 39-47.

Molla, A., Abareshi, A. and Cooper, V. (2014), "Green IT beliefs and pro-environmental IT practices among IT professionals", Information Technology and People, Vol. 27, No. 2, pp. 129-154.

Murphy, P.R. and Poist, R.F. (2000), "Green logistics strategies: an analysis of usage patterns", Transportation Journal, Vol. 40, No. 2, pp. 5-16.

Nawrocka, D., Brorson, T. and Lindhqvist, T. (2009), "ISO 14001 in environmental supply chain practices", Journal of Cleaner Production, Vol. 17, No. 16, pp. 1435-1443.

Olugu, E.U., Wong, K.Y. and Shaharoun, A.M. (2011), "Development of key performance measures for the automobile green supply chain", Resources, Conservation and Recycling, Vol. 55, No. 6, pp. 567-579. 
Parmigiani, A., Klassen, R.D. and Russo, M.V. (2011), "Efficiency meets accountability: Performance implications of supply chain configuration, control, and capabilities", Journal of Operations Management, Vol. 29, No. 3, pp. 212-223.

Prajogo, D., Tang, A.K. and Lai, K.-H. (2012), "Do firms get what they want from ISO 14001 adoption?: An Australian perspective", Journal of Cleaner Production, Vol. 33, pp. 117-126.

Puente, M.R., Arozamena, E.R. and Evans, S. (2015), "Industrial symbiosis opportunities for small and medium sized enterprises: preliminary study in the Besaya region (Cantabria, Northern Spain)." Journal of Cleaner Production, Vol. 87, pp. 357-374.

Rao, P. (2002), "Greening the supply chain: a new initiative in South East Asia", International Journal of Operations and Production Management, Vol. 22, No. 6, pp. 632-655.

Rao, P. and Holt, D. (2005), "Do green supply chains lead to competitiveness and economic performance?", International Journal of Operations and Production Management, Vol. 25, No. 9, pp. 898-916.

Robèrt, K.-H. (2000), "Tools and concepts for sustainable development, how do they relate to a general framework for sustainable development, and to each other?", Journal of Cleaner Production, Vol. 8, No. 3, pp. 243-254.

Rostamzadeh, R., Govindan, K., Esmaeili, A. and Sabaghi, M. (2015), "Application of fuzzy VIKOR for evaluation of green supply chain management practices", Ecological Indicators, Vol. 49, pp. 188-203.

Rowley, J. and Slack, F. (2004), "Conducting a literature review", Management Research News, Vol. 27, No. 6, pp. 31-39.

Saghiri, S. and Hill, A. (2014), "Supplier relationship impacts on postponement strategies", International Journal of Production Research, Vol. 52, No. 7, pp. 2134-2153.

Salimifard, K., Shahbandarzadeh, H. and Raeesi, R. (2012), Green transportation and the role of operation research, Paper presented at the Int. Conf. Traffic Transp. Eng. (ICTTE 2012).

Sarkis, J. (1998), "Evaluating environmentally conscious business practices", European Journal of Operational Research, Vol. 107, No. 1, pp. 159-174.

Sarkis, J., Koo, C. and Watson, R.T. (2013), "Green information systems and technologies-this generation and beyond: Introduction to the special issue", Information Systems Frontiers, Vol. 15, No. 5, pp. 695.

Sarkis, J., Zhu, Q. and Lai, K.-h. (2011), "An organizational theoretic review of green supply chain management literature", International Journal of Production Economics, Vol. 130, No. 1, pp. 1-15.

Saunders, M.N. (2011), Research methods for business students, 5/e, Pearson Education, India. 
Savita, K., Dominic, P. and Ramayah, T. (2014), The adoption of green information technologies and systems as a driver within green SCM. Paper presented at the Computer and Information Sciences (ICCOINS), 2014.

Setterstrom, A. (2008), The natural resource-based view of a firm: Strategic opportunities in IT. Paper presented at the Annual Academy of Management Meetings, Anaheim, CA.

Seuring, S. and Müller, M. (2008), "From a literature review to a conceptual framework for sustainable supply chain management", Journal of Cleaner Production, Vol. 16, No. 15, pp. 1699-1710.

Sheu, J.-B., Chou, Y.-H. and Hu, C.-C. (2005), "An integrated logistics operational model for green-supply chain management", Transportation Research Part E: Logistics and Transportation Review, Vol. 41, No. 4, pp. 287-313.

Soda, S., Sachdeva, A. and Garg, R.K. (2016), "Literature review of multi-aspect research works carried out on the concept and implementation of GSCM", International Journal of Industrial and Systems Engineering, Vol. 23. No, 2, pp. 223-253.

Srivastava, S.K. (2007), "Green supply-chain management: a state-of-the-art literature review", International Journal of Management Reviews, Vol. 9, No. 1, pp. 53-80.

Srivastava, S.K. (2008), "Network design for reverse logistics", Omega, Vol. 36, No. 4, pp. 535-548.

Standing, C., Jackson, P., Sarkis, J. and Zhu, H. (2008), "Information technology and systems in China's circular economy: Implications for sustainability", Journal of Systems and Information Technology, Vol. 10, No. 3, pp. 202-217.

Sundarakani, B., De Souza, R., Goh, M., Wagner, S. M. and Manikandan, S. (2010), "Modeling carbon footprints across the supply chain", International Journal of Production Economics, Vol. 128, No. 1, pp. 43-50.

Tibben-Lembke, R.S. (2002), "Life after death: reverse logistics and the product life cycle", International Journal of Physical Distribution and Logistics Management, Vol. 32, No. 3, pp. 223-244.

Tranfield, D., Denyer, D. and Smart, P. (2003), "Towards a methodology for developing evidence-informed management knowledge by means of systematic review", British Journal of Management, Vol. 14, No. 3, pp. 207-222.

Tseng, M.-L. and Bui, T.-D. (2016), "Identifying eco-innovation in industrial symbiosis under linguistic preferences: A novel hierarchical approach", Journal of Cleaner Production, Vol. 140, No. 3, pp. 1376-1389.

Tseng, M.-L., Chiang, J.H. and Lan, L.W. (2009), "Selection of optimal supplier in supply chain management strategy with analytic network process and Choquet integral", Computers and Industrial Engineering, Vol. 57, No. 1, pp. 330-340.

Tseng, M.-L. and Chiu, A.S. (2013), "Evaluating firm's green supply chain management in linguistic preferences", Journal of Cleaner Production, Vol. 40, pp. 22-31. 
Tseng, M.-L., Divinagracia, L. and Shi, L. (2011), "Achieving green outsourcing performance in uncertainty", African Journal of Business Management, Vol. 5, No. 14, pp. 5946.

Tseng, M.-L., Tan, K. and Chiu, A.S. (2015), "Identifying the competitive determinants of firms' green supply chain capabilities under uncertainty", Clean Technologies and Environmental Policy, Vol. 18, No. 5, pp. 1-16.

Tseng, M.-L., Tan, R.R. and Siriban-Manalang, A.B. (2013), "Sustainable consumption and production for Asia: sustainability through green design and practice", Journal of Cleaner Production, Vol. 40, pp. 1-5.

Tseng, M.L. and Chiu, A.S. (2012), "Grey-entropy analytical network process for green innovation practices", Procedia-Social and Behavioral Sciences, Vol. 57, pp. 10-21.

Tsoulfas, G.T. and Pappis, C.P. (2008), "A model for supply chains environmental performance analysis and decision making", Journal of Cleaner Production, Vol. 16, No. 15, pp. 1647-1657.

Uddin, M. and Rahman, A.A. (2012), "Energy efficiency and low carbon enabler green IT framework for data centers considering green metrics", Renewable and Sustainable Energy Reviews, Vol. 16, No. 6, pp. 4078-4094.

Vachon, S. and Klassen, R.D. (2006), "Green project partnership in the supply chain: the case of the package printing industry", Journal of Cleaner Production, Vol. 14, No. 6, pp. 661-671.

Vachon, S. and Klassen, R.D. (2007), "Supply chain management and environmental technologies: the role of integration", International Journal of Production Research, Vol. 45, No. 2, pp. 401-423.

Vachon, S. and Klassen, R.D. (2008), "Environmental management and manufacturing performance: The role of collaboration in the supply chain", International Journal of Production Economics, Vol. 111, No. 2, pp. 299-315.

Van Hoek, R.I. (1999), "From reversed logistics to green supply chains", Supply Chain Management: An International Journal, Vol. 4, No. 3, pp. 129-135.

Walker, H., Di Sisto, L. and McBain, D. (2008), "Drivers and barriers to environmental supply chain management practices: Lessons from the public and private sectors", Journal of Purchasing and Supply Management, Vol. 14, No. 1, pp. 69-85.

Wee, H.-M., Lee, M.-C., Jonas, C. and Wang, C.E. (2011), "Optimal replenishment policy for a deteriorating green product: Life cycle costing analysis", International Journal of Production Economics, Vol. 133, No. 2, pp. 603-611.

$\mathrm{Wu}$, H.-J. and Dunn, S.C. (1995), "Environmentally responsible logistics systems", International Journal of Physical Distribution and Logistics Management, Vol. 25, No. 2, pp. 20-38.

Wu, Z. and Pagell, M. (2011), "Balancing priorities: Decision-making in sustainable supply chain management", Journal of Operations Management, Vol. 29, No. 6, pp. 577-590. 
Yang, C.-L., Lin, R.-J., Krumwiede, D., Stickel, E. and Sheu, C. (2013), "Efficacy of purchasing activities and strategic involvement: an international comparison", International Journal of Operations and Production Management, Vol. 33, No. 1, pp. 49-68.

Yeh, W.-C. and Chuang, M.-C. (2011), "Using multi-objective genetic algorithm for partner selection in green supply chain problems", Expert Systems with Applications, Vol. 38, No. 4, pp. 4244-4253.

Zhu, Q. and Sarkis, J. (2004), "Relationships between operational practices and performance among early adopters of green supply chain management practices in Chinese manufacturing enterprises", Journal of Operations Management, Vol. 22, No. 3, pp. 265-289.

Zhu, Q. and Sarkis, J. (2007), "The moderating effects of institutional pressures on emergent green supply chain practices and performance", International Journal of Production Research, Vol. 45, No. 18-19, pp. 4333-4355.

Zhu, Q., Sarkis, J. and Geng, Y. (2005), "Green supply chain management in China: pressures, practices and performance", International Journal of Operations and Production Management, Vol. 25, No. 5, pp. 449-468.

Zhu, Q., Sarkis, J. and Lai, K.-H. (2007), "Green supply chain management: pressures, practices and performance within the Chinese automobile industry", Journal of Cleaner Production, Vol. 15 No. 11, pp. 1041-1052.

Zhu, Q., Sarkis, J. and Lai, K.-H. (2008), "Confirmation of a measurement model for green supply chain management practices implementation", International Journal of Production Economics, Vol. 111, No. 2, pp. 261-273. 